\title{
The Unique Communication Pattern of Japanese and Indonesian Families Shaping Specific Character to their Children
}

\author{
Dwi Rini Sovia Firdaus ${ }^{\left.1,{ }^{*}\right)}$, Alo Karyati ${ }^{2}$, Rakhe S. Rakasiwi ${ }^{3}$, Tubagus Nugraha ${ }^{4}$
}

${ }^{1}$ Dept of Communication Science, Pakuan University, Jl. Pakuan Bogor 16129, Indonesia

${ }^{2}$ Dept of Japanese Literature, Pakuan University, Jl. Pakuan Bogor 16129, Indonesia

${ }^{3,4}$ Student of Dept of Communication Science \& Dept of Japanese Literature, Pakuan University, Jl. Pakuan Bogor 16129

${ }^{*}$ Corresponding author e-mail: rinifirdaus@unpak.ac.id

Diterima: 17 Desember 2021 | Disetujui: 10 Februari 2022 | Publikasi online: 25 Februari 2022

\section{ABSTRACT}

The character-building system in Japan has become a role model in Indonesia. The initiators of education policies in Indonesia are intensively promoting character building as a solution to the decline in the quality of human resources. Character building in Japan and in Indonesia are carried out by the nuclear family at home. This study maps the differences in the communication patterns of Indonesian and Japanese parents in teaching character building to their children. Parents of productive age 17-50 years were used as respondents, had junior high school to postgraduate education, and had children aged 0-15 years. Questionnaires were distributed using google forms to Japanese people in Japan and Indonesians in Indonesia. It was found that the value of hard work in Indonesian families stems from the desire to avoid uncertainty and parents' pragmatic thinking. In Japanese families, avoiding uncertainty teaches children a spirit of enthusiasm. Hofstede's cultural dimensions cannot explain the source of the spirit of togetherness in Indonesian and Japanese families, as well as the source of the spirit of hard work, and responsibility in Japanese families.

Keywords: children's character, cultural communication pattern, Hofstede's cultural dimensions, Japanese and Indonesian families, productive-age parents title of the work, journal citation and DOI.

Published under Department of Communication and Community Development Science, IPB University and in association with Forum Komunikasi Pembangunan Indonesia and Asosiasi Penerbitan Jurnal Komunikasi Indonesia. 


\section{INTRODUCTION}

Several studies have stated that cultural shifts are generally caused by the penetration of foreign cultures, a domino effect of globalization. The $4 \mathrm{~T}$ revolution (technology, telecommunications, transportation, and tourism) is sufficient evidence that foreign cultural influences have begun to blur boundaries between regions, thus forming a global village as predicted by McLuhan in $2011^{l}$ (Logan, 2011). This phenomenon increases cross-cultural contacts so that the uniqueness of once-isolated cultures is getting lost (Castells, 2011). The intense penetration of foreign cultures can cause some people to feel that their original identity has become obsolete because it is no longer in line with globalization (Firdaus et al., 2018). They then experienced an identity crisis and consequently left the self to join the net ${ }^{2}$. Wallerstein has emphasized that the entry of foreign cultures through electronic media, print media, internet media, and social media is a new form of colonization (Wallerstein, 2011). Razmin et al. (2013) explains that imperialism or colonialism is no longer used to describe a direct conquest, which exhibits violence and coercion nowadays. This new form of colonization is more about changing attitudes.

The character-building system in Japan has been a role model in Indonesia for quite a long time. This system is applied from kindergarten to university level. The education system in Japan is similar to the system in Indonesia because of the four levels, namely 6, 3, 3, 4, meaning six years of elementary school, three years in junior and senior high school, and four years in college. The historical factor of Indonesia being colonized by the Japanese causes this similarity. The recent change in Indonesia measures graduation based on logical scores, while the Japanese people remain focused more on character and personality development, where teacher's evaluation is based on student's daily learning performance.

The initiators of educational policies in Indonesia have recently been aggressively promoting character building as an antidote to educational problems in Indonesia. By prioritizing character building, they hope that the educational community will explore the affective side of students, and education is not only emphasized on the cognitive side to pursue grades. By paying more attention to character, the school can produce good morals, intelligence, and creative graduates.

\section{The Communication Culture of Japanese Society}

Nobody can separate culture from communication because culture not only determines who talks to whom, about what, and how the person becomes a message, as well as the conditions for sending, paying attention, and interpreting messages (Holliday et al., 2004; Suryandari, 2019). According to Iqbal (2018), one of the countries that highly respects cultural values that can survive in the era of technological progress with a very complex public life is Japan.

The harmonious blend of modern and traditional reflects in the pattern of people's lives. This harmony can be seen from the progress of science, technology, and industry without ignoring cultural values. Currently, the cultural uniqueness of the Japanese people remains a part of their lives (Iqbal, 2018). Japanese society interacts with non-verbal communication, namely conveying messages that are quite complicated to interpret, but the Japanese have made this communication style their communication culture. Still, according to Iqbal (2018), to better understand Japanese communication culture, it is essential to comprehend how non-verbal communication affects Japanese communication culture, communication patterns, and ethics in communicating with Japanese people in social interaction. Understanding this can provide additional knowledge about how Japanese culture communicates. According to Samovar et al. (2015), non-verbal communication includes all stimuli in the form of communication produced by individuals, and the use of the environment by individuals, which have potential message value for the sender or receiver. This definition includes both intentional and

\footnotetext{
${ }^{1}$ McLuhan says our modern 'electronic' life is like living in a big village - a global village - where everyone is a part of the stories and experiences of others.

${ }^{2}$ The self means to remain in its original identity, while the net means to idenfity itself as a global network society.
} 
unintentional behavior as part of the overall communication event. We send a lot of non-verbal messages without realizing that they mean something to other people.

\section{Formation of Child Character at School and Home}

When a great earthquake struck the northeastern part of Japan, the world was amazed by the mental strength of the Japanese people. They place the public interest and standard safety above private interests. We often hear about their orderly queuing culture and stories of lost wallets that always come back. The mental character and personality of the Japanese people certainly did not just come out nowhere. Education in schools has a significant role, running dynamically with traditions and values instilled by families at home.

Along with school, family is a significant factor in character development in Japan. From here, cooperation, communication, and harmony between schools and families for the sake of children's education began to build (Putri \& Izmayanti, 2015)(Iqbal, 2018). Relatively different conditions occur in Indonesia. Collaboration and communication between the family and the school are not done intensively. Parents are not directly involved with their children's activities at school, so there is a separate division of roles between teachers and parents.

In Japan, all school activities are always carried out with the spirit of togetherness (tomodachi, shinsetsu, nakayoku), the spirit of hard work (gambaru), enthusiasm (genki), and responsibility (jibun no koto o jibun de suru) (Davies \& Ikeno, 2002). At the end of kindergarten education, when children have to give a brief impression after receiving their diploma, many of them, in fact almost all of them, will talk about the Gambaru, Tomodachi, and the jibun no koto o jibun de suru (Goto et al., 2020). The process of internalizing the results of character building is evident.

We need to rethink the current education system in Indonesia, which forces schools to pursue pseudonumbers through shortcuts by ignoring the process of developing student character. If character building becomes an essential point of national education, we can start creating it in the family environment at home. The purpose of this study is to compare the patterns of cultural communication carried out in Japanese and Indonesian-Sundanese families in building a spirit of togetherness, hard work, enthusiasm, and responsibility. This mapping is used to analyze the process of enculturation in the Indonesian-Sundanese family environment, comparing it with that applied by families in Japan. Furthermore, an evaluation of the strengths and weaknesses of communication patterns in families in both cultures is carried out. This research is intended to uncover the origin of character building in Indonesia (Sundanese) and in Japan.

\section{Parenting Patterns in Japan are also Imperfect}

Parenting patterns can be influenced by the culture or customs of the people in a country itself, as in Japanese society, it is called ikuji. In the life of Japanese society, the concept of $i k u j i$ has long been embedded, and this concept states that mothers should nurture, raise and discipline children. This $i k u j i$ concept gives the mother full responsibility for the child's affairs (Andarini et al., 2017). Unbalanced parenting can also affect a child's personality, for example, by not having complete parents as usual. In the case of single parents in Japan, mothers must bear burdens that include monitoring children's physical and mental development, protecting children, educating children, and meeting economic needs (Andarini et al., 2017). This pattern has a positive and negative impact on children's development.

Between 2005 and 2015, the number of births in Japan decreased from 1,062,530 to 1,005,677. In the same period, violence against children increased from 34,472 to 103,286 (Statistic Bureau, 2021). During those ten years, violence cases against children aged 0-2 per 1,000 children of the same age showed a steep increase from 2 to 7 cases (Goto et al., 2020). Although the number of beatings for toddlers aged 3-5 years born in 2010 decreased by $60 \%$, sometimes toddlers are still beaten by family members to become good children (Baba et al., 2020).

Spock (2001) explains that "in the older days, most parents spanked their children on the assumption that this was necessary to make them behave. In the twenty-first century, [parents] have come to 
realize that children can be well behaved, cooperative, and polite without ever having been physically punished" This statement shows a significant change in educating children in America. Meanwhile, Japan is going through a similar but slower transition process. In his writings, Baba et al. (2020) explained that the prohibition of corporal punishment on children in Japan was only effective in April 2020. Changing the law alone is not enough to change people's behavior. Recognizing this condition, the Ministry of Health, Labor, and Welfare started a campaign in 2019 to ban the "whip of love/"Ai no Muchi," a term that refers to the violent discipline or physical punishment for children. Equal Employment and Child and Family Policy Bureau, Ministry of Health, Labor and Welfare Distribution promoted a campaign about parenting without corporal punishment (www.mhlw.go.jp).

Children's character relates to the application of corporal punishment in educating children. According to Baba et al. (2020), being a male, lives with siblings, has young parents, comes from a low socioeconomic level, is at high risk of experiencing beatings in the family. In other words, if the child lives with both parents or grandparents, and the child's father is a respondent from the survey, the risk is lower. The result of Baba's research showed three findings, namely: traditional parenting styles, social inequality, and the need for father involvement in parenting.

The first and third problems are related. In an in-depth study of Japanese families with two children, there are differences in parenting patterns depending on the birth order and gender of the child. The first son is more resistant to the father's parenting style. A father in Japanese culture wants his first son to be a role model for the family. Even in western culture, a study from the Netherlands explains that a father with stereotyped attitudes according to gender roles uses physical control in boys more than in girls as his parenting strategy (Endendijk et al., 2017). The style of educating children is passed down from generation to generation (Bailey et al., 2009), shaped by social and cultural patterns (Goto et al., 2020).

Baba et al. (2020) explain a relationship between child beating and parental job instability and fewer work hours to spend more time at home. A study in the Journal of Epidemiology explains that limited access to children's education in families experiencing socio-economic problems is not beneficial for Japanese children even though the government has provided fund for child welfare for these families (Kachi et al., 2020). The conclusion of Baba's research, changing culture in parenting in Japan requires concerted efforts and creative efforts at various levels to turn rhetoric into action. The action is in changing family dynamics rather than strengthening gender-specific strategies. Women are encouraged to excel in society, and men are encouraged to excel at home in educating children. Making both of them have equal responsibilities in society and at home can reduce the old paradox that leads to violence against children, including the imposition of corporal punishment in Japanese families.

\section{Growing Fear and Shame}

Shimoda said, if a mother ignores her child, the child will not grow up to be a person who is respected and appreciated. The formation of a child's personality is closely related to the mother's role in educating and caring for her child at home (Putri \& Izmayanti, 2015). When it comes to parenting, mothers in Japan have their patterns. In the parenting pattern of children aged $0-1.5$ years, when the child still needs protection from his mother, the mother takes care of it with physical touch (body contact). Examples include breastfeeding, bathing, and sleeping together. The goal is to create a close and safe relationship between the mother and her child (Putri \& Izmayanti, 2015).

In the pattern of parenting children aged $1.5-3$ years, Japanese mothers always maintain nutritious family food and support their children's health. In addition, mothers begin to instill moral education in the discipline, courtesy, and cultural values that the community believes. From an early age, children are accustomed by their mothers to making good habits at home, such as sitting, eating habits, and entering or leaving the Japanese house (Putri \& Izmayanti, 2015).

Japanese mothers practice the culture of manners in their babies. The mother talks and hums greetings, then the baby imitates slowly. When the baby answers again, the mother moves the baby's head and shoulders (Benedict, 1989). Japanese mothers also train their children to be obedient, as in consuming vegetables. Japanese mothers do this by speaking softly and lovingly: "eat it, and eat a little, and then 
you can eat it tomorrow" (Davies \& Ikeno, 2002). In addition, Japanese mothers also began to educate their children to get used to and regularly defecate to the toilet. Japanese mothers do not get used to their babies using diapers because it can cause the baby to feel uncomfortable. Therefore, she always trains so that her baby can get used to the toilet. The mother's way is to pay attention to the signs and study the expression on the child's face. If the child looks like he wants to defecate, the mother immediately takes him to the toilet, patiently waits while whistling low, and the child will learn to realize by himself the meaning of his mother's urge (Benedict, 1989).

Apart from moral education, mothers have also begun to train children about scientific challenges such as how to count, master language, and vocabulary to prepare their children for school. In their daily activities, Japanese mothers converse with their children to train them to speak. When children aged 46 years start hanging out in the community, Japanese mothers guide them to get along well and have good behaviour to blend in with the community. Mothers teach about group living, manners, and selfdiscipline. In addition, shame education is also taught to their children. Mothers always tell their children not to do embarrassing things when hanging out.

Japanese mothers introduce shame to their children by making fun of them. When a five or six-yearold cries, the mom says, "you are not a girl, you are a boy" or "look at that baby, he is not crying." When another baby visits, the mom carries him and say, "I will pick him up because I want a nice baby like him." The child will hit his mom, and say "no, we don't want another baby." I will be a good and obedient child." The panic generated by such ridicule is one way of cultivating a fear of being laughed at by others at this age. The fear of being laughed at mingled with the panic of losing everything that kept him safe. This fear will remain imprinted until adulthood (Benedict, 1989). This shame is instilled very well by Japanese mothers to their children. Children should understand the meaning of shame as early as possible. Japanese mothers are always serious and have zero-tolerance when it comes to educating their children. A child cannot be different from others because it will make the child ostracized by his group of friends (Ghiamitasya, 2012). As in Japan, parenting to foster fear and shame is also applied in Minangkabau culture since childhood (Firdaus, 2019) and Sundanese culture.

Mothers will return to work when their children enter elementary school to earn extra money to increase their children's education costs because children's education is essential. Apart from parents, the government also plays a significant role in every stage of raising children in Japan. The government provides allowances for childcare, places for consultation, facilitated with children's playgrounds, and places for discussion. The parenting style used by Japanese mothers is like a healthy diet, training children's intelligence to prepare knowledgeable and educated people. In addition, educating the culture of shame so that children can prepare themselves when living in society and familiarize children to be independent, work hard, earnestly, disciplined and polite are very instrumental in creating a young generation who have eminent personalities (Putri \& Izmayanti, 2015).

Parents and the government pay attention to children's welfare and childcare, such as providing care allowances received by Japanese mothers every three months. In addition, support from the environment and schools, especially teachers who also guide and direct children in everyday life during the teaching and learning process. Teachers also play a role in producing Japanese youth with good character. With care from parents, especially mothers, plus support from the government, schools, and the Japanese community, this plays a significant role in creating a generation of superior children with good character. Japanese people believe that a good education will elevate a person's degree, thus making young Japanese people always want to learn and have a higher education target to develop further technology and innovative works in Japan that are recognized by the world (Putri \& Izmayanti, 2015).

This research begins by revealing some facts and history behind the teaching of the four virtues taught by Japanese culture and applied in several extended families in Japan and at basic schools such as playgroups, kindergarten, and elementary schools. The four virtues are tomodachi, shinsetsu, nakayoku (the spirit of togetherness), gambaru (the spirit of hard work), genki (enthusiasm), and jibun no koto o jibun de suru (responsibility). Though these values of kindness are still being taught in basic schools, but with the changing conditions of young Japanese parents, there are values that are no 
longer taught. Meanwhile, the image of Japanese character-building in Indonesia is still a role model until now. This study measures how young Indonesian families can adopt the four values but still maintain their own cultural values. The relevance of this research in development communication is that the value of kindness taught by Japanese culture can be adopted as a substance for characterbuilding in basic schools in Indonesia and as additional knowledge for young families at home. Communication patterns can be built as for family communication at home and interpersonal communication in schools so that it can support the character development of younger generation in Indonesia.

\section{RESEARCH METHODS}

The research was conducted online using google form to distribute questionnaire for Japanese respondents living in Japan and Indonesian living in Indonesia particularly from Sundanese culture. This study is to confirm whether the Japanese and Indonesian culture are still inherent in productiveage parents so it affects the upbringing methods towards their children. A non-probability sampling is used to select respondents in Japan, namely by purposive sampling using the google form as a tool. A snowball sampling was also carried out due to the distance barrier between the researchers in Indonesia and the respondents in Japan. Meanwhile, the selection of respondents in Indonesia uses purposive sampling by distributing questionnaires through a google form as well. The Hofstede's cultural dimensions were the parameter for instilled cultural value in the family, they are:

1. Power Distance Index (PDI); Individuals in a group that adheres to a high PDI will accept the existence of a hierarchy and recognize that everyone is naturally in certain positions without being questioned.

2. Individualism versus Collectivism (IDV); a condition in which a person is integrated into a group or not.

3. Uncertainty Avoidance Index (UAI); Individuals from cultures with high UAI tend to be emotional because they usually want to minimize a completely unclear and unusual situation and slowly move towards a more definite change implementing rules, laws, and regulations.

4. Indulgence versus Restraint (IVR); This culture concerns the extent to which members of the society try to control their desires and impulses. Indulgence is a community characteristic that wants self-satisfaction and a relatively free life, related to enjoying life and having fun. Restraint further suppresses the level of need and regulates it using strict social norms.

5. Masculinity versus Femininity (MAS); Masculine culture emphasizes competition, assertiveness, materiality, ambition, and power. Meanwhile, feminine culture prioritizes good relationships and quality of life. In his research, Taras et al. (2010) found that men are more self-directed than women. On the other hand, women value virtue more than men. As a result, men's responses are more focused as they get closer to cultural values, so the relationship between value and result congruence is more robust for men than for women.

6. Short vs. Long-Term Orientation (LTO); It relates to an inherent interest in the future versus the past and present. In a long-term-oriented society, they value pragmatism which is oriented towards future appreciation because it is austerity. They love persistence and adaptation to changing circumstances. In short-term oriented communities, they value tradition, are more proud of their country, are more willing to preserve authenticity, value social obligations, and are more likely to return gifts and assistance from others (Hofstede, 2012; Khlif, 2016). The LTO cultural dimension is Hofstede's adaptation to the eastern cultural dimension, which consists of four components that represent Confucian values in Chinese society, namely: (1) the structure of a relationship; (2) savings; (3) persistence; and (4) a sense of shame (Hofstede et al., 2010; Wu, 2006).

This study portrays the understanding of productive-age parents in Japan and Indonesia - Sundanese about their cultural values, how they inherit it to shape their children's character. Respondents are productive-age parents (17-50 years old) male and female, education from junior high school to postgraduate, and they have children aged 0-15 years. The survey results are processed using SPSS, a Likert scale of $1-4$, an average analysis which is performed to make the high and low criteria. 
According to (Gay \& Diehl, 1992), in a correlational and comparison research, the sample size is at least 30 sample units. This is the basis for taking the number of samples in this study. Testing the correlation between Hofstede's cultural dimensions and the construction of children's character was carried out using Spearman's rank test. Testing the correlation between parents' circumstances and Hofstede's cultural dimensions also towards the construction of children's character uses Chi-Square test.

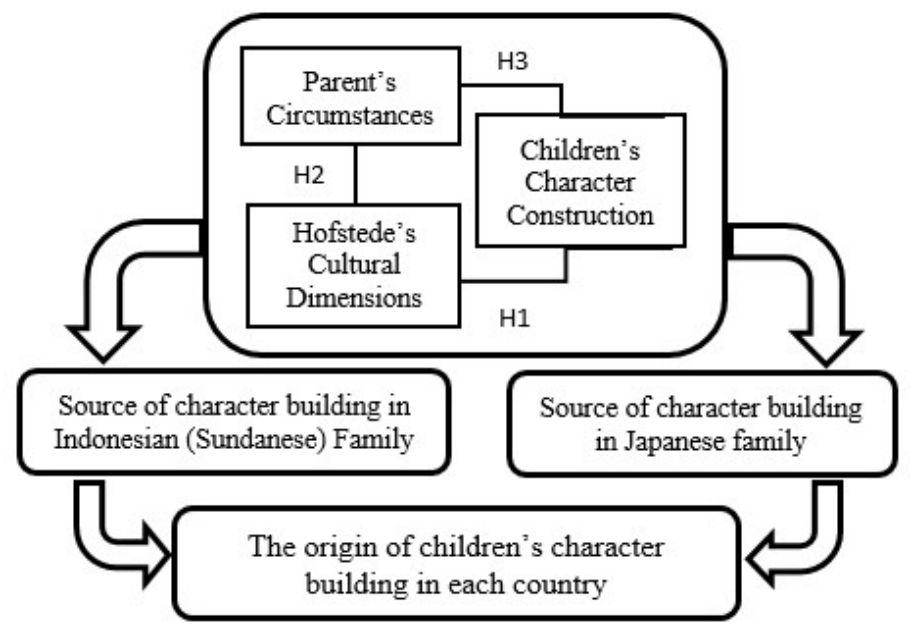

Figure 1. Research Framework

\section{RESULTS AND DISCUSSION}

\section{Applying Hofstede's Concept}

Every group of people carries a standard set of mental programs, and this is their culture. Each person belongs to several different groups at the same time. We cannot avoid the fact that we carry many layers of mental programming within each of us, which correspond to varying levels of culture (Hofstede et al., 2010). Mental programs from these various levels are not always harmonious (sometimes cultural values conflict with the values of the younger generation). In modern society, religious values may conflict with generational values, gender values may conflict with practices within an organization. The indicator originally initiated by Hofstede is also used to measure cultural distance or the national culture model. (Hofstede et al., 2010). This study found that Indonesian Sundanese families (78\%) and Japanese families (79\%) had a reasonably high power-distance, which means these families teach their children that everyone is naturally in certain positions without being questioned. Recognition of a hierarchy in society has been taught from an early age by these two types of families.

A study from Bornstein et al. (1991) explained that parenting would be different in collective and individual cultures. Parents in collective cultures (such as Japan) tend to emphasize the values of obedience, dependability, and good behaviour. Parents in individual cultures (such as the US) teach self-confidence, independence, and creative behaviour. Children are educated to follow the rules and norms. On the other hand, children are allowed to have autonomy and are encouraged to explore freely in their environment. This example represents a culture of collectivism and individualism (Firdaus et al., 2018; Mintu, 1992), keeping urbanity, complexity, and other global factors constant (Bornstein et al., 1991). Indonesian Sundanese families $(62 \%)$ are slightly more collective than Japanese families (55\%), meaning families enjoy being part of a particular group and pass this pleasure on to their children.

The value of uncertainty avoidance for Indonesian - Sundanese and Japanese families both touched $57 \%$. This figure is slightly above the equilibrium figure. Both types of families are accustomed to instilling rules to predict what will happen to their children in the future. Children are taught to obey their parent's rules because this is for their own good. A condition where a high value of uncertainty avoidance is related to a high value of restraint because families tend to suppress the level of need and 
regulate it using strict social norms. Indonesian Sundanese families $(82 \%)$ are much more restrained than Japanese families (64\%).

The value of femininity for Indonesian Sundanese families (63\%) is quite high, but the value of femininity for Japanese families is higher (68\%). Families that prioritize femininity prioritize good relations and quality of life rather than promoting competition, ambition, and power. In this study, the Japanese family was superior. The value of short vs long-term orientation of Indonesian Sundanese families was inversely proportional to that of Japanese families. Indonesian Sundanese families are more long-term oriented (56\%), while Japanese families are more short-term oriented $(68 \%)$. Indonesian Sundanese families value pragmatic nature, which is oriented towards respect for the future. Therefore, children are taught to be frugal, diligent in work, and flexible in relationships because this manifests the ability to adapt to changing circumstances. Meanwhile, Japanese families that value tradition more, are prouder of their country and culture, want to preserve authenticity, value social obligations, and are more likely to repay gifts and favours from others, also closely related to a high femininity value. According to $\mathrm{Wu}$ (2006), the Long Term Orientation cultural dimension is Hofstede's adaptation to the eastern cultural dimension, which consists of four components that represent Confucian values in Chinese society, namely: (1) the structure of a relationship; (2) savings; (3) persistence; (4) have a sense of shame $(\mathrm{Wu}, 2006)(\mathrm{Wu}, 2006)(\mathrm{Wu}, 2006)(\mathrm{Wu}, 2006)(\mathrm{Wu}$, 2006)(Wu, 2006) (Hofstede et al., 2010; Wu, 2006). These four cultural values are taught to children in Indonesia, especially in the Sunda region because of the close cultural relationship between China and Indonesia most of whom live as traders. The inheritance of these four goodness is identical with the eastern nature taught to Indonesian children, so they can become pleasant individuals who are easily accepted by the society. The following is a data processing table about the distribution of cultural dimensions in both types of families:

Table 1. Distribution of Hofstede's cultural dimensions

\begin{tabular}{|c|c|c|c|}
\hline \multirow{2}{*}{ No } & \multirow{2}{*}{ Hofstede's Cultural Dimensions } & Indonesia (Sundanese) & Japanese \\
\hline & & $\%$ & $\%$ \\
\hline \multirow[t]{4}{*}{1} & Power Distance & & \\
\hline & Low & 78 & 79 \\
\hline & High & 22 & 21 \\
\hline & TOTAL & 100 & 100 \\
\hline \multirow[t]{4}{*}{2} & Collectivism vs Individualism & & \\
\hline & Collectivism & 62 & 55 \\
\hline & Individualism & 38 & 45 \\
\hline & TOTAL & 100 & 100 \\
\hline \multirow[t]{4}{*}{3} & Uncertainty Avoidance & & \\
\hline & Low & 43 & 43 \\
\hline & High & 57 & 57 \\
\hline & TOTAL & 100 & 100 \\
\hline \multirow[t]{4}{*}{4} & Indulgence vs Restraint & & \\
\hline & Indulgence & 18 & 36 \\
\hline & Restraint & 82 & 64 \\
\hline & TOTAL & 100 & 100 \\
\hline \multirow[t]{4}{*}{5} & Femininity vs Masculinity & & \\
\hline & Femininity & 63 & 68 \\
\hline & Masculinity & 37 & 32 \\
\hline & TOTAL & 100 & 100 \\
\hline \multirow[t]{4}{*}{6} & Short vs Long-Term Orientation & & \\
\hline & Short-Term Orientation & 44 & 68 \\
\hline & Long-Term Orientation & 56 & 32 \\
\hline & TOTAL & 100 & 100 \\
\hline
\end{tabular}

\section{Cultural Values that Construct Children's Character}

The values of hard work, enthusiasm, and responsibility are quite strongly inversely related to the values of collectivism. The collective culture of Indonesian families reduces the spirit of hard work, enthusiasm, and children's responsibility. The value of togetherness instilled in children by Japanese 
families is quite strongly inversely related to the value of collectivism. Thus, the high value of Japanese family collectivism makes the value of the spirit of togetherness decrease. High collectivism values harm teaching the value of togetherness in Japanese children, while for Indonesian Sundanese children, high collectivism values have a terrible impact on decreasing the value of hard work, decreasing enthusiasm, and a sense of responsibility instilled by parents.

The high value of uncertainty avoidance in Indonesian Sundanese families is associated with hard work, while it is associated with high enthusiasm in Japanese families. The high value of uncertainty avoidance in both families forces Indonesian Sundanese families to instill the value of hard work on their children, while Japanese families invest enthusiasm. Although both have high restraint values, Indonesian Sundanese families suppress the level of need and regulate it using strict social norms, compared to Japanese families. This situation is closely and significantly related to the inculcation of the values of enthusiasm and responsibility by Indonesian - Sundanese families. Meanwhile, in Japanese families, the value of restraint reduces the inculcation of the value of responsibility.

The high value of femininity in Indonesian - Sundanese and Japanese families does not have anything to do with teaching the values of the spirit of togetherness, hard work, enthusiasm, and responsibility in children. The value of long-term orientation in Indonesian Sundanese families is related to teaching the value of hard work in children. In contrast, Japanese families who are more concerned with shortterm orientation have nothing to do with teaching the values of togetherness, hard work, enthusiasm, and responsibility to their children.

Table 2. Cultural values that construct children's character

\begin{tabular}{|c|c|c|c|c|}
\hline \multirow{3}{*}{$\begin{array}{l}\text { Children's } \\
\text { characters }\end{array}$} & \multicolumn{2}{|c|}{ Indonesian (Sundanese) } & \multicolumn{2}{|c|}{ Japanese } \\
\hline & \multicolumn{4}{|c|}{ Power Distance } \\
\hline & Corr. Coef & Sig 2-tailed & Corr. Coef & Sig 2-tailed \\
\hline Togetherness & .148 & .436 & -.225 & .232 \\
\hline Hard work & -.045 & .814 & .018 & .923 \\
\hline Enthusiasm & -.052 & .783 & -.002 & .991 \\
\hline \multirow[t]{2}{*}{ Responsibility } & -.009 & .963 & .243 & .196 \\
\hline & \multicolumn{4}{|c|}{ Collectivism vs Individualism } \\
\hline Togetherness & -.213 & .259 & -.306 & .100 \\
\hline Hard work & -.296 & .112 & -.231 & .220 \\
\hline Enthusiasm & .267 & .154 & -.225 & .231 \\
\hline \multirow[t]{2}{*}{ Responsibility } & .256 & .172 &,- 206 & .276 \\
\hline & \multicolumn{4}{|c|}{ Uncertainty Avoidance } \\
\hline Togetherness & .143 & .450 & .221 & .241 \\
\hline Hard work & .313 & .092 & .167 & .377 \\
\hline Enthusiasm & .024 & .900 & .332 & .073 \\
\hline \multirow[t]{2}{*}{ Responsibility } & .209 & .267 & .065 & .732 \\
\hline & \multicolumn{4}{|c|}{ Indulgence vs Restraint } \\
\hline Togetherness & .189 & .318 & .138 & .467 \\
\hline Hard work & .198 & .293 & -.229 & .223 \\
\hline Enthusiasm & .370 & .044 & -.053 & .781 \\
\hline \multirow[t]{2}{*}{ Responsibility } & 352 & .057 & -.341 & .065 \\
\hline & \multicolumn{4}{|c|}{ Femininity vs Masculinity } \\
\hline Togetherness & -.249 & .185 & .089 & .638 \\
\hline Hard work & -.016 & .934 & -.082 & .668 \\
\hline Enthusiasm & -.175 & .355 & -.205 & .277 \\
\hline \multirow[t]{2}{*}{ Responsibility } & -.105 & .581 & -.090 & .637 \\
\hline & \multicolumn{4}{|c|}{ Short vs Long-Term Orientation } \\
\hline Togetherness & -.120 & .526 & .109 & .568 \\
\hline Hard work & .264 & .159 & -.004 & .985 \\
\hline Enthusiasm & .110 & .565 & -.013 & .945 \\
\hline Responsibility & .168 & .376 & .011 & .955 \\
\hline $\begin{array}{l}\text { Correlation Coe } \\
0.26-0.50=\mathrm{qu} \\
0.51-0.75=\mathrm{str} \\
0,76-0,99=\mathrm{ve} \\
\text { Corr. Coefficien }\end{array}$ & $0-0.25=\mathrm{v}$ & connection & & \\
\hline
\end{tabular}


Sig $<0.05=$ significantly correlated

\section{Parents of Productive Age that Inherited Cultural Values}

From the Chi-Square correlation test between the parent's circumstances of Indonesian - Sundanese and Japanese families and the inherited cultural values, there is only one correlation, namely the age of Indonesian - Sundanese parents with the value of long-term orientation taught to children. The older the parents, the more they teach to appreciate the practical nature oriented towards respect for the future. Children are taught to save, persevere, and adapt easily to changing circumstances.

Table 3. The correlation between parents' circumstances and inherited cultural values

\begin{tabular}{|c|c|c|}
\hline \multirow{2}{*}{ Parent condition } & Indonesian (Sundanese) & Japanese \\
\hline & \multicolumn{2}{|c|}{ Power Distance } \\
\hline Parent's age & .154 & .883 \\
\hline Parent's sex & .169 & .794 \\
\hline Parent's education & .571 & .904 \\
\hline \multirow[t]{2}{*}{ Child's age } & .233 & .579 \\
\hline & \multicolumn{2}{|c|}{ Collectivism vs Individualism } \\
\hline Parent's age & .355 & .488 \\
\hline Parent's sex & .281 & .352 \\
\hline Parent's education & .738 & .931 \\
\hline \multirow[t]{2}{*}{ Child's age } & .592 & .400 \\
\hline & \multicolumn{2}{|c|}{ Uncertainty Avoidance } \\
\hline Parent's age & .351 & .142 \\
\hline Parent's sex & .387 & .973 \\
\hline Parent's education & .618 & .002 \\
\hline \multirow[t]{2}{*}{ Child's age } & .678 & .509 \\
\hline & \multicolumn{2}{|c|}{ Indulgence vs Restraint } \\
\hline Parent's age & .482 & .107 \\
\hline Parent's sex & .607 & .160 \\
\hline Parent's education & .665 & .926 \\
\hline \multirow[t]{2}{*}{ Child's age } & .799 & .282 \\
\hline & \multicolumn{2}{|c|}{ Femininity vs Masculinity } \\
\hline Parent's age & .291 & .276 \\
\hline Parent's sex & .227 & .880 \\
\hline Parent's education & 624 & .994 \\
\hline \multirow[t]{2}{*}{ Child's age } & 475 & .331 \\
\hline & \multicolumn{2}{|c|}{ Short vs Long-Term Orientation } \\
\hline Parent's age & .049 & .092 \\
\hline Parent's sex & .661 & .184 \\
\hline Parent's education & .437 & .721 \\
\hline Child's age & .243 & .297 \\
\hline
\end{tabular}

Asymp. Sig $<0.05$ there is a significant connection

\section{Parents of Productive Age in Constructing Children's Character}

Japanese parents instill the spirit of togetherness at home as their children get older. The higher the child's age, the more often they are taught about the nature of togetherness. The higher the education of parents, the more often they teach about hard work. For the Indonesian Sundanese parents, the circumstances of the parents have nothing to do with constructing children's character.

Uniquely in both cultures, the spirit of togetherness is inversely related to the desire to gather. This is because the value of togetherness is obtained from cyberspace and the parents who are used as respondents are young couples who, according to the survey, use the internet to socialize. The high collective value of the Japanese family reduces their desire to build a spirit of togetherness. Likewise, Indonesian families who like to gather together have a negative impact on inculcating the values of hard work, enthusiasm, and responsibility. 
Table 4. Parent's circumstances in constructing children's character

\begin{tabular}{|c|c|c|}
\hline \multirow{2}{*}{ Parent's circumstances } & Indonesian (Sundanese) & Japanese \\
\hline & \multicolumn{2}{|c|}{ Spirit of togetherness } \\
\hline Parent's age & .375 & .304 \\
\hline Parent's sex & .071 & .257 \\
\hline Parent's education & .181 & .111 \\
\hline \multirow[t]{2}{*}{ Child's age } & .199 & .007 \\
\hline & \multicolumn{2}{|c|}{ Hard work } \\
\hline Parent's age & .482 & .725 \\
\hline Parent's sex & .266 & .376 \\
\hline Parent's education & .318 & .046 \\
\hline \multirow[t]{2}{*}{ Child's age } & .319 & .275 \\
\hline & \multicolumn{2}{|c|}{ Enthusiasm } \\
\hline Parent's age & .279 & .834 \\
\hline Parent's sex & .435 & .545 \\
\hline Parent's education & .684 & .443 \\
\hline \multirow[t]{2}{*}{ Child's age } & .623 & .471 \\
\hline & \multicolumn{2}{|c|}{ Responsibility } \\
\hline Parent's age & .161 & .737 \\
\hline Parent's sex & .492 & .559 \\
\hline Parent's education & .472 & .061 \\
\hline Child's age & .217 & .887 \\
\hline
\end{tabular}

Asymp. Sig $<0.05$ there is a significant correlation

In the Indonesian Sundanese family, the cultivation of hard work comes from the uncertainty avoidance and long-term orientation culture. The teaching of responsibility and enthusiasm comes from the restraint culture, while Hofstede's cultural dimensions could not explain the origin of togetherness. The condition of productive-age parents has nothing to do with the construction of children's character. Meanwhile, in the communication pattern of Japanese family, the cultivation of enthusiasm comes from the uncertainty avoidance culture. Hofstede's cultural dimensions could not explain the origin of togetherness, hard work, and responsibility. The essence of togetherness is taught as children get older, and the higher the education of parents, the more they teach about the importance of hard work.

Table 5. The comparison of the origin of children's character construction

\begin{tabular}{|c|c|c|c|}
\hline No & Variables & Indonesia (Sundanese) & Japanese \\
\hline 1 & Collectivism & $\begin{array}{l}\text { Reduce the spirit of hard work, } \\
\text { enthusiasm, and responsibility }\end{array}$ & Reduce the spirit of togetherness \\
\hline 2 & Uncertainty avoidance & Teaches hard work & Teaches enthusiasm \\
\hline 3 & Restraint & $\begin{array}{l}\text { Teaches responsibility and } \\
\text { significantly teaches enthusiasm }\end{array}$ & Inversely to teaching responsibility \\
\hline 4 & Long-term orientation & $\begin{array}{l}\text { Teaches hard work. Older } \\
\text { parents teach hard work more } \\
\text { often }\end{array}$ & $\begin{array}{l}\text { None } \\
\text { (Because Japanese family is short-term } \\
\text { orientation) }\end{array}$ \\
\hline 5 & Parent's circumstances & $\begin{array}{l}\text { Parent's circumstances have } \\
\text { nothing to do with children's } \\
\text { character construction }\end{array}$ & $\begin{array}{l}\text { Hard work is taught by higher educated } \\
\text { parents }\end{array}$ \\
\hline 6 & Others & None & Togetherness is taught to older children \\
\hline
\end{tabular}

\section{CONCLUSION}

This research reveals how Japanese culture educate its younger generation. It was found that there are four good values that are often taught in basic schools such as playgroups, kindergartens, and at the elementary schools. As time goes by, the extended families are more involved in teaching the good values compared to nuclear families, and unfortunately it is still taught in early-level schools. This study compares how young Japanese and Indonesian families teach these four virtues nowadays. Differences are discovered when measured by Hofstede's cultural dimension parameters. It can be seen that in addition to the parents' different condition, cultural background and the government's 
educational policies in Indonesia can create a different approach when teaching the four good Japanese cultural values in Indonesia.

This study suggests an alternative character-building teaching pattern for early-level schools. Lessons about hard work and enthusiasm are influenced by the habit of Indonesians who want to avoid uncertainty. Meanwhile, the sense of responsibility and enthusiasm comes from the habit of exercising restraint, and the value of hard work comes from the habit of Indonesians who tend to be long-term oriented. Instilling a sense of togetherness is taught to older children. This communication pattern can be used as a reference for teaching the four Japanese values of kindness to children, both at home and in early-level schools in Indonesia. This is how this research has the contribution for development communication, especially in Indonesia.

\section{ACKNOWLEDGEMENTS}

I would like to express my sincere gratitude for LPPM Pakuan University for providing sufficient fund for this research.

\section{REFERENCES}

Andarini, C. A., Dewi, N. M. A. A., \& Damayanti, S. (2017). Konsep Ikuji yang Diterapkan oleh Tokoh Umi Suzuki yang Tercermin dalam Drama Risou no Musuko. Jurnal Humanis Fakultas Ilmu Budaya Unud, 21(1), 209-214.

Baba, S., Eshak, E. S., Shirai, K., Fujiwara, T., Yamaoka, Y., \& Iso, H. (2020). Factors associated with family member's spanking of 3.5-year-old children in Japan. Journal of Epidemiology, 30(10), 464-473. https://doi.org/10.2188/jea.JE20190160

Bailey, J. A., Hill, K. G., Oesterle, S., \& Hawkins, J. D. (2009). Parenting Practices and Problem Behavior Across Three Generations: Monitoring, Harsh Discipline, and Drug Use in the Intergenerational Transmission of Externalizing Behavior. Developmental Psychology, 45(5), 1214-1226. https://doi.org/10.1037/a0016129

Benedict, R. (1989). The Chrysanthemum and The Sword: Patterns of Japanese Culture. Houghton Mifflin Company.

Bornstein, M., Tal, J., \& Tamis-LeMonda, C. (1991). Parenting in Cross-Cultural Perspective: The United States, France, and Japan. Crosscurrents in Contemporary Psychology. Cultural Approaches to Parenting, 69-90.

Castells, M. C. (2011). The Rise of the Network Society. In Blackwell Publishing Ltd: Vol. I (Second). Blackwell Publishing Ltd. https://doi.org/10.1007/978-1-60327-951-2

Davies, R. J., \& Ikeno, O. (2002). The Japanese Mind: Understanding Contemporary Japanese Culture (Vol. 148). Tuttle Publishing.

Endendijk, J. J., Groeneveld, M. G., van der Pol, L. D., van Berkel, S. R., Hallers-Haalboom, E. T., Bakermans-Kranenburg, M. J., \& Mesman, J. (2017). Gender Differences in Child Aggression: Relations With Gender-Differentiated Parenting and Parents' Gender-Role Stereotypes. Child Development, 88(1), 299-316. https://doi.org/10.1111/cdev.12589

Firdaus, D. R. S. (2019). The Coexistence Between Matrilineal Family Structures and the Religious Order of the Minangkabau Community. Jurnal Komunikasi Ikatan Sarjana Komunikasi Indonesia, 04(01), 18-25. https://doi.org/https://doi.org/10.25008/jkiski.v4i1.223

Firdaus, D. R. S., Lubis, D., Soetarto, E., \& Susanto, D. (2018). Potret budaya masyarakat minangkabau berdasarkan keenam dimensi budaya Hofstede. Sodality: Jurnal Sosiologi Pedesaan. https://doi.org/10.22500/sodality.v6i2.23229

Gay, L. R., \& Diehl, P. L. (1992). Research Methods for Business and Management, Macmillan Publishing Company, 1992, MD Shields. 9780023408, 1992.

Ghiamitasya, M. (2012). Perubahan Peran Ayah dalam Pengasuhan Anak di Jepang pada Era Shoushika. Japanology, 1(1), 107-115. 
Goto, A., Surkan, P. J., \& Reich, M. R. (2020). Challenges to changing the culture of parenting in Japan. Journal of Epidemiology, 30(10), 427-428. https://doi.org/10.2188/jea.JE20190265

Hofstede, G. (2012). Hofstede's cultural dimensions: Understanding workplace values around the world. 1-5.

Hofstede, G., Hofstede, G. J., \& Minkov, M. (2010). Cultures and Organizations: Software of the Mind. In McGraw Hill. McGraw Hill. https://doi.org/10.1177/030630709201700409

Holliday, A., Hyde, M., \& Kullman, J. (2004). Intercultural communication: an advanced resource book. Routledge, Taylor \& Francis Group. https://doi.org/10.1080/14708470802230871

Iqbal, C. I. (2018). Budaya Komunikasi Dalam Masyarakat Jepang. Walasuji : Jurnal Sejarah Dan Budaya, 9(1), 129-140. https://doi.org/10.36869/wjsb.v9i1.25

Kachi, Y., Kato, T., \& Kawachi, I. (2020). Socio-economic disparities in early childhood education enrollment: Japanese population-based study. Journal of Epidemiology, 30(3), 143-150. https://doi.org/10.2188/jea.JE20180216

Khlif, H. (2016). Hofstede's cultural dimensions in accounting research: A review. In Meditari Accountancy Research (Vol. 24, Issue 4). https://doi.org/10.1108/MEDAR-02-2016-0041

Logan, R. (2011). McLuhan misunderstood: setting the record straight. In Razón y palabra (Issue 76).

Mintu, A. T. (1992). Cultures and Organizations: Software of the Mind. Journal of International Business Studies, 23(2), 362-365. https://doi.org/10.1057/jibs.1992.23

Putri, D. M., \& Izmayanti, D. K. (2015). Pola Asuh Dalam Nuclear Family di Jepang. Artikel Ilmiah Hasil Penelitian Mahasiswa Jurusan Sastra Asia Timur, 1(3), 1-10.

Razmin, N. H. ., Anuar, N. I. ., Yusoff, N. D. ., \& Mahdi, N. . N. (2013). Globalisasi sebagai Salah Satu Kolonialisme Bentuk Baru dan Kesan Kepada Ekonomi. Proceeding of the International Conference on Social Science Research, ICSSR, (e-ISBN 978-967-11768-1-8), 4-5 June 2013. Penang Malaysia. Organized by WorldConference.Net, 1-12. https://doi.org/10.1017/CBO9781107415324.004

Samovar, L. A., Porter, R. E., McDaniel, E. R., \& Roy, C. S. (2015). Intercultural Communication A Reader. Cengage LEarning.

Spock, B. (2001). Dr. Spock's The First Two Years: The Emotional and Physical Needs of Children from Birth to Age 2 (p. 176). Pocket Books.

Statistic Bureau. (2021). E-stat. Ministry of Internal Affairs and Communication. https://www.estat.go.jp/en

Suryandari, N. (2019). Buku Ajar KOMUNIKASI LINTAS BUDAYA. PMN.

Taras, V., Kirkman, B. L., \& Steel, P. (2010). Examining the Impact of Culture's Consequences: A Three-Decade, Multilevel, Meta-Analytic Review of Hofstede's Cultural Value Dimensions. Journal of Applied Psychology, 95(3), 405-439. https://doi.org/10.1037/a0018938

Wallerstein, I. (2011). The Modern World-System I. University of California Press.

Wu, M. (2006). Hofstede's Cultural Dimensions 30 Years Later. International Communication Studies, $X V(1), 33-42$. https://doi.org/10.5539/ijbm.v6n5p93 